\title{
Implementasi Pembelajaran dalam Jaringan (Daring) Ramah Anak Abad 21
}

\author{
Rika Febrianti \\ STAI STAI Al-Aqidah Al-Hasyimiyyah, Jakarta, Indonesia \\ E-mail: februarika81@gmail.com
}

\begin{tabular}{l}
\hline Article Info \\
\hline Article History \\
Received: 2021-07-1 \\
Revised: 2021-08-15 \\
Published: 2021-09- \\
\\
Keywords: \\
Implementation; \\
Learning; \\
School; \\
Child Friendly.
\end{tabular}

\begin{abstract}
This study aims to describe the implementation of learning in the 21st century childfriendly network. The research method chosen is descriptive analysis. The subjects in this study are principals, teachers, students, and parents of students with the object of research including the implementation of the Child Friendly School Program in schools. The data analysis technique used by researchers in a qualitative approach is that the researchers themselves are assisted with several tools to collect useful data or information to answer problems. The results show that the implementation of the Child Friendly School Program includes (1) Communication, socialization of the Child Friendly School Program to all related parties such as teachers, students and parents; (2) Human resources and infrastructure resources that support the Implementation of the Child Friendly School Program, in the 21st century there is a positive attitude and commitment from the school to continue implementing the Child Friendly School Program; Bureaucratic Structure, the organizational structure of the Children's School Program is adjusted to the Organizational Structure of a particular School. The learning model used is adjusted to teach students who are planned or designed, implemented and evaluated systematically so that students can achieve learning objectives effectively and efficiently. The supporting factors are human resources, infrastructure resources, and financial resources that support the implementation of the Child Friendly School Program and the inhibiting factor is the environmental conditions in schools.
\end{abstract}

\begin{tabular}{l}
\hline Artikel Info \\
\hline Sejarah Artikel \\
Diterima: 2021-07-12 \\
Direvisi: 2021-08-15 \\
Dipublikasi: 2021-09-10
\end{tabular}

Kata kunci: Implementasi; Pembelajaran; Sekolah;

Ramah Anak.

\begin{abstract}
Abstrak
Penelitian ini bertujuan untuk mendeskripsikan implementasi pembelajaran dalam jaringan ramah anak abad 21, Metode penelitian yang dipilih adalah deskriptif analisis, Subjek dalam penelitian ini yaitu kepala sekolah, guru, siswa, dan orang tua siswa dengan objek penelitian meliputi implementasi Program Sekolah Ramah Anak di sekolah. Teknik analisis data yang digunakan peneliti dalam pendekatan kualitatif adalah peneliti sendiri dibantu dengan beberapa alat untuk mengumpulkan data atau informasi yang bermanfaat untuk menjawab permasalahan, Hasil penelitian menunjukkan bahwa implementasi Program Sekolah Ramah Anak, meliputi (1) Komunikasi, adanya sosialisasi mengenai Program Sekolah Ramah Anak kepada seluruh pihak terkait seperti guru, siswa dan orang tua; (2) Sumber daya manusia dan sumber daya sarana prasarana yang mendukung Implementasi Program Sekolah Ramah Anak, pada abad 21 adanya sikap yang positif dan komitmen pihak sekolah untuk terus mengimplementasikan Program Sekolah Ramah Anak; Struktur Birokrasi, struktur organisasi Program Sekolah Anak disesuaikan dengan Struktur Organisasi Sekolah tertentu. Model Pembelajaran yang digunakan disesuaikan dengan membelajarkan subjek didik yang direncanakan atau didesain, dilaksanakan dan dievaluasi secara sistematis agar subjek didik dapat mencapai tujuan pembelajaran secara efektif dan efisien. Faktor pendukungnya adalah sumber daya manusia, sumber daya sarana prasana, dan sumber daya finansial yang mendukung dalam pengimplementasian Program Sekolah Ramah Anak dan faktor penghambatnya adalah pada kondisi lingkungan yang ada disekolah.
\end{abstract}

\section{PENDAHULUAN}

Proses pendidikan dari masa ke masa terus melakukan inovasi, sesuai dengan perkembangan dan kemampuan manusia itu sendiri, sehingga pendidikan mengalami kemajuan yang cukup pesat. Dunia pendidikan nasional sedang dihadapkan pada masalah yang sangat mendasar dalam mengembangkan kemampuan dan membentuk watak serta peradaban bangsa yang bermartabat dalam rangka mencerdaskan kehi- 
dupan bangsa agar menjadi wahana untuk mengembangkan potensi peserta didik menjadi manusia yang beriman dan bertakwa kepada Tuhan Yang Maha Esa, berakhlak mulia, sehat, berilmu, cakap, kreatif, mandiri dan menjadi warga negara yang demokratis serta bertanggung jawab, seperti yang diamanatkan oleh undang-undang sisdiknas, Pendidikan tidak lepas dari belajar dan pembelajaran yang merupakan sesuatu yang tidak pernah berakhir sejak manusia ada dan berkembang sampai akhir zaman nanti. Belajar adalah salah satu aktivitas yang selalu dilakukan dan dialami oleh manusia di dalam kandungan, buaian, tumbuh berkembang dari anak-anak remaja sehingga menjadi dewasa, sampai ke liang lahat, sesuai dengan prinsip pembelajaran sepanjang hayat.

Pemenuhan hak-hak anak ini menuntut para pendidik untuk memberikan pelayanan semaksimal mungkin dan pola pendidikan yang berfokus pada peserta didik (student center). Sekolah hakikatnya sebagai agen pelaksana proses pendidikan yang harus memiliki budaya ramah dalam menjalankan fungsinya untuk mencapai tujuan pendidikan. Berbagai berita kekerasan di sekolah sering terjadi pada siswa akhir-akhir ini. Ironisnya lagi kekerasan ini dilakukan oleh pihak sekolah baik itu guru, karyawan ataupun lainnya. Hal itu berdampak pada fisik dan psikologis siswa. Sekolah tampak kehilangan budaya ramah dalam mendidik siswa dalam melaksanakan tugasnya menghasilkan siswa berbudi pekerti dan cerdas secara intelektual, tetapi juga belum bisa mendidik siswa dengan cara yang santun.

Pendidikan ramah anak (PRA) dapat dimaknai sebagai suatu satuan lembaga pendidikan yang dapat memfasilitasi dan memberdayakan potensi anak. Untuk memberdayakan potensi anak di satuan lembaga pendidikan tentunya harus memprogramkan segala sesuatunya yang menyebabkan potensi anak bisa tumbuh dan berkembang, berpartisipasi dan terlindungi dari tindakan kekerasan dan diskriminasi. Selain harus menciptakan program sekolah yang memadai, sekolah juga harus menciptakan lingkungan yang kondusif dan edukatif.

Dalam pemenuhan hak dan perlindungan anak khususnya di bidang pendidikan ditegaskan dalam Pasal 28C Undang-Undang Dasar Negara Republik Indonesia Tahun 1945 yang menyebutkan bahwa "Setiap orang berhak mengembangkan diri melalui pemenuhan kebutuhan dasar, berhak mendapat pendidikan dan memperoleh manfaat dari ilmu pengetahuan dan teknologi, seni dan budaya, demi meningkatkan kualitas hidupnya dan demi kesejahteraan umat manusia".

Berbagai permasalah seputar perlindungan dan pemenuhan hak-hak anak, sekolah berbasis ramah anak menjadi program yang dibutuhkan oleh semua anak Indonesia dalam menempuh jenjang pendidikan dari tingkat dasar sampai tingkat menengah. Sekolah ramah anak atau yang disingkat menjadi SRA adalah satuan pendidikan formal dan nonformal yang aman, bersih dan sehat, peduli dan berbudaya lingkungan hidup, mampu menjamin, memenuhi, menghargai hakhak anak dan perlindungan anak dari kekerasan, diskriminasi, dan perlakuan salah lainnya serta mendukung partisipasi anak terutama dalam perencanaan, kebijakan, pembelajaran, pengawasan, dan mekanisme pengaduan terkait pemenuhan hak dan perlindungan anak di pendidikan.

Dalam penyelenggaraannya, sekolah memiki tujuan yaitu memenuhi, menjamin, dan melindungi hak anak melalui Sekolah Ramah Anak dan memastikan bahwa satuan pendidikan mengembangkan minat, bakat, dan kemampuan anak serta mempersiapkan anak untuk bertanggungjawab kepada kehidupan yang toleran, saling menghormati, serta bekerjasama untuk kemajuan dan semangat perdamaian, oleh karena itu dalam proses kegiatan belajar dan mengajar di sekolah diharapkan menggunakan model pendidikan yang berbasis ramah anak, Pendidikan di sekolah idealnya mampu menumbuhkan suasana yang bisa membuat siswa saling menghargai, kebebasan berpendapat dan keterlibatan peserta didik dalam berbagai aktivitas di sekolah. Sehingga, peserta didik dapat melatih kemampuannya untuk hidup bersama dalam perbedaan sehingga akan siap menghadapi kehidupan ditengah-tengah masyarakat.

\section{Tinjauan Pustaka}

1. Pengertian Belajar

Belajar pada hakikatnya adalah suatu proses yang ditandai dengan adanya perubahan pada diri seseorang. Perubahan sebagai hasil dari proses belajar dapat diindikasikan dalam berbagai bentuk seperti berubah pengetahuan, pemahaman, sikap dan tingkah laku, kecakapan, keterampilan dan kemampuan, serta perubahan aspek-aspek yang lain yang ada pada individu yang belajar, dalam kehidupan manusia sehari-hari hampir tidak pernah dapat terlepas dari kegiatan belajar, baik ketika seseorang melaksanakan aktivitas sendiri, maupun didalam suatu kelompok tertentu. Dipahami ataupun tidak 
dipahami, sesungguhnya semua aktivitas di dalam kehidupan sehari-hari kita merupakan kegiatan belajar, dengan demikian dapat kita katakan, tidak ada ruang dan waktu dimana manusia dapat melepaskan dirinya dari kegiatan belajar, dan itu berarti pula bahwa belajar tidak pernah dibatasi usia, tempat maupun waktu, karena perubahan yang menuntut terjadinya aktivitas belajar itu juga tidak pernah berhenti.

\section{Pengertian Pembelajaran}

Kata atau istilah pembelajaran dan penggunaannya masih tergolong baru, yang mulai populer semenjak lahirnya UU No.20 tahun 2003 tentang Sisdiknas pasal 1 ayat 2 menyatakan bahwa, pembelajaran adalah proses interaksi peserta didik dengan pendidik dan sumber belajar pada suatu lingkungan belajar. Kamus besar bahasa Indonesia dalam Thobroni mendefinisikan kata pembelajaran berasal dari kata ajar yang berarti petunjuk yang diberikan kepada orang supaya diketahui atau diturut, sedangkan pembelajaran adalah proses, cara, perbuatan menjadikan orang atau makhluk hidup untuk belajar, pembelajaran dapat didefinisikan sebagai suatu sistem atau proses membelajarkan subjek didik yang direncanakan atau didesain, dilaksanakan dan dievaluasi secara sistematis agar subjek didik dapat mencapai tujuan pembelajaran secara efektif dan efisien.

Sedangkan pembelajaran berdasarkan makna leksikal berarti proses, cara, perbuatan mempelajari, perbedaan esensial istilah ini dengan pengajaran adalah pada tindak ajar, Pada pengajaran guru mengajar, siswa belajar. Guru mengajar dalam perspektif pembelajaran adalah guru menyediakan fasilitas belajar bagi siswanya, jadi, subjek dalam pembelajaran adalah siswa, Selanjutnya menurut Gagne, dkk dalam Warsita mengatakan bahwa pembelajaran adalah suatu sistem yang bertujuan untuk membantu proses belajar peserta didik, yang berisi serangkaian peristiwa yang dirancang, disusun sedemikian rupa untuk mempengaruhi dan mendukung terjadinya proses belajar peserta didik yang bersifat internal, Menurut Dimyati dan Mudjiono dalam buku karya Sagala, bahwasanya pembelajaran adalah kegiatan guru secara terprogram dalam desain instruksional, untuk membuat belajar secara aktif, yang menekankan pada penyediaan sumber belajar.

\section{Pembelajaran Daring}

Definisi Pembelajaran adalah proses interaksi siswa dengan pendidikan dan sumber belajar pada suatu lingkungan belajar, pembelajaran merupakan upaya yang dilakukan oleh pendidik agar dapat terjadi proses interaksi guna untuk mendapatkan pengetahuan dan keterampilan pada siswa, Daring merupakan singkatan dari komunikasi dalam jaringan, yaitu cara berkomunikasi yang cara penyampaian dan penerima pesan dilakukan dengan melalui internet. Komunikasi dilakukan dengan memanfaatkan jaringan internet yang ada pada saat ini, jaringan yang mudah akan mempercepat penyampaian dan penerimaan pesan.

Pembelajaran secara daring bertujuan untuk memberikan layanan yang baik dan bermutu dalam pembelajaran melalui jaringan yang bersifat terbuka untuk menjangkau pada orang yang lebih banyak dan luas. Pembelajaran secara daring ini dilakukan dengan keterlibatan langsung antara pendidik dan siswa dalam proses pelaksanaan pembelajaran, pembelajaran daring ini tidak dibatasi oleh ruang dan waktu.

\section{METODE PENELITIAN}

Penelitian ini bertujuan untuk mendeskripsikan implementasi pembelajaran dalam jaringan ramah anak abad 21, adapun metode penelitian yang dipilih adalah deskriptif analisis, Subjek dalam penelitian ini yaitu kepala sekolah, guru, siswa, dan orang tua siswa dengan objek penelitian meliputi implementasi Program Sekolah Ramah Anak di sekolah, sedangkan teknik analisis data yang digunakan peneliti dalam pendekatan kualitatif ini dibantu dengan beberapa alat untuk mengumpulkan data atau informasi yang bermanfaat untuk menjawab permasalahan.

\section{HASIL DAN PEMBAHASAN}

Secara konseptual, pendidikan ramah anak adalah pendidikan yang secara sadar berupaya kuat untuk menjamin dan memenuhi hak-hak dan perlindungan anak dalam setiap aspek kehidupan secara terencana dan bertangung jawab. Tujuan pendidikan ramah anak ialah mewujudkan satuan lembaga pendidikan yang dapat menjamin dan memenuhi hak-hak dan perlindungan anak Indonesia, hal ini sesuai dengan tujuan pendidikan nasional, UUD 45, Undang -undang No. 20 tahun 2003 tentang Sistem Pendidikan Nasional, dan prinsip-prinsip perlindungan anak. 
Guna memastikan terlaksananya pendidikan ramah anak disatuan pendidikan, maka harus memiliki prinsip-prinsip perlindungan anak, yakni; tanpa kekerasan, tanpa diskriminasi, kepentingan terbaik bagi anak dan hak tumbuh dan berkembang, serta penghargaan terhadap pendapat anak, yang dapat diintegrasikan ke dalam bidang-bidang implementasi, yakni; kebijakan, kurikulum, manajemen dan peraturan sekolah, sarana, prasarana dan lingkungan, serta relasi sehari-hari antara pemaku kepentingan.

Penyelenggaraan proses pendidikan dan pembelajaran secara sistematis dan berkesinambungan, para pendidik dan tenaga kependidikan di sekolah diharapkan menyelenggarakan pendidikan dan berprilaku terpelajar. Prilaku terpelajar ditampilkan dalam bentuk pencapaian prestasi akademik, menunjukkan prilaku yang beretika dan berakhlak mulia, memiliki motivasi belajar yang tinggi, kreatif, disiplin, bertanggung jawab, serta menunjukan karakter diri sebagai warga masyarakat, warga negara dan bangsa.

Satuan lembaga pendidikan harus dapat menciptakan suasana yang kondusif agar anak didik merasa nyaman dan dapat mengekspresikan potensinya. Agar tercipta suasana kondusif tersebut maka ada beberapa aspek yang perlu diperhatikan terutama: Perencanaan program sekolah yang sesuai dengan tahap-tahap pertumbuhan dan perkembangan anak didik. Anak tidak harus dipaksakan melakukan sesuatu, tetapi dengan program tersebut anak secara otomatis terdorong untuk mengeksplorasi dirinya. Faktor penting yang perlu diperhatikan sekolah adalah partisipasi aktif anak terhadap berbagai kegiatan yang diprogramkan, namun sesuai dengan kebutuhan anak, lingkungan satuan lembaga pendidikan yang mendukung, jika suasana dapat tercipta di sekolah. Maka suasana di lingkungan sekolah sangat kondusif untuk menumbuhkembangkan potensi anak karena anak dapat mengeks-presikan dirinya secara leluasa sesuai dengan dunianya, disamping itu, penciptaan lingkungan yang bersih, ketersediaan air minum yang sehat, bebas dari sarang kuman dan gizi yang memadai merupakan faktor yang penting bagi pertumbuhan dan perkembangan anak.

Satuan lembaga pendidikan ramah anak merupakan institusi yang mengenal dan menghargai hak anak (untuk memperoleh pendidikan, kesehatan, kesempatan bermain dan bersenang-senang), melindungi dari kekerasan dan pelecehan, dapat mengungkapkan pandangan secara bebas dan berperan serta dalam mengambil keputusan sesuai dengan kapasitas mereka. Lembaga pendidikan yang ramah anak juga harus menanamkan tanggung jawab untuk menghormati hak-hak orang lain, kemajemukan dan menyelesaikan masalah perbedaan tanpa melakukan kekerasan.

Sedangkan dengan kemajuan zaman dan teknologi pada saat sekarang ini, dunia pendidikan pun berkembang dengan sangat cepat, Ciri abad 21 menurut Kemendikbud adalah tersedianya informasi dimana saja dan kapan saja (informasi\}, adanya implementasi penggunaan mesin (komputasi), mampu menjangkau segala pekerjaan rutin (otomatisasi) dan bisa dilakukan dari mana saja dan kemana saja (komunikasi). Ditemukan bahwa dalam kurun waktu 20 tahun terakhir telah terjadi pergeseran pembangunan pendidikan ke arah ICT sebagai salah satu strategi manajemen pendidikan abad 21 yang di dalamnya meliputi tata kelola kelembagaan dan sumber daya manusia. (Soderstrom, From, Lovqvist, \& Tornquist, 2011) 1. Abad ini memerlukan transformasi pendidikan secara menyeluruh sehingga terbangun kualitas guru yang mampu memajukan pengetahuan, pelatihan, ekuitas siswa dan prestasi siswa. (Darling-Hammond, 2006 ; Azam \& Kingdon, 2014).

Ciri abad 21 menurut Hernawan (dalam Hidayat dan Patras) 2 adalah meningkatnya interaksi antar warga dunia baik secara langsung maupun tidak langsung, semakin banyaknya informasi yang tersedia dan dapat diperoleh, meluasnya cakrawala intelektual, munculnya arus keterbukaan dan demokkratisasi baik dalam politik maupun ekonomi, memanjangnya jarak budaya antara generasi tua dan generasi muda, meningkatnya kepedulian akan perlunya dijaga keseimbangan dunia, meningkatnya kesadaran akan saling ketergantungan ekonomis, dan mengaburnya batas kedaulatan budaya tertentu karena tidak terbendungnya informasi.

Hidayat menjelaskan kebutuhan pendidikan abad 21 menurut Patrick Slattery dalam bukunya yang berjudul "Curriculum Development In The Postmodern" yaitu pendidikan yang berdasarkan pada beberapa konsep berikut:

1. Pendidikan harus diarahkan pada perubahan sosial, pemberdayaan komunitas, pembebasan pikiran, tubuh dan spirit (mengacu pada konsep yang dikembangkan oleh Dorothy\}

2. Pendidikan harus berlandaskan pada 7 hal utama (mengacu pada konsep yang dikembangkan oleh Thich Nhat Hanh\}, yaitu 
tidak terikat pada teori, ideology, dan agama; jangan berpikir sempit bahwa pengetahuan yang dimiliki adalah yang paling benar, tidak memaksakan kehendak pada orang lain baik dengan kekuasaan, ancaman, propaganda maupun pendidikan, peduli terhadap sesama, jangan memelihara kebencian dan amarah, jangan kehilangan jatidiri, jangan bekerja di tempat yang menghancurkan manusia dan alam.

3. Konteks pembelajaran, pengembangan kurikulum dan penelitian diterapkan sebagai kesempatan untuk menghubungkan siswa dengan alam semesta (mengacu pada konsep yang dikembangkan oleh David Ort)

4. Membuat guru merasa sejahtera dalam kegiatan pembelajaran (mengacu pada konsep yang dikembangkan oleh Dietrich Bonhoeffer)

Pendidikan yang mengimplementasikan visi 21th century, 21th century readiness merupakan kesiapan dalam menyambut abad 21. UNESCO telah membuat 4 (empat) pilar pendidikan untuk menyongsong abad 21, yaitu:

1. Learning to how (belajar untuk mengetahui)

2. Learning to do (belajar untuk melakukan)

3. Learning to be (belajar untuk mengaktualisasikan diri sebagai individu mandiri yang berkepribadian)

4. Learning to live together (belajar untuk hidup bersama)

Pendidikan yang membangun kompetensi "partnership 21st Century Learning" yaitu framework pembelajaran abad 21 yang menuntut peserta didik memiliki keterampilan, pengetahuan, dan kemampuan dibidang teknologi, media dan informasi, keterampilan pembelajaran, inovasi, keterampilan hidup dan Kompetensi "partnership 21st Century Learning " mengacu pada format pendidikan abad 21 yang diusung oleh Hermawan (2006), yaitu:

1. Cyber (e-learning) dimana pembelajaran dilakukan dengan mengoptimalkan penggunaan teknologi informasi.

2. Open and distance learning dimana pembelajaran abad 21 dapat dilakukan dengan model pembelajaran jarak jauh, tidak terbatas dan dilakukan dengan memanfaatkan bantuan teknologi informasi dan komunikasi.

3. Quantum Learning, yaitu menerapkan metode belajar yang disesuaikan dengan cara kerja.

4. Cooperative Learning, yaitu pembelajaran yang menggunakan kelompok sebagai upaya menumbuhkan kerjasama antar peserta didik.
5. Society Technology Science, yaitu konsep interdisipliner yang diterapkan untuk mengintegrasikan permasalahan dalam ilmu pengetahuan, teknologi dan masyarakat.

6. Accelerated Learning, yaitu mengembangkan kemampuan dalam menyerap dan memahami informasi secara cepat sehingga dapat meningkatkan kemampuan belajar secara lebih efektif.

\section{A. Kurikulum dan Metode Yang Cocok Dengan Kriteria Pendidikan abad 21}

1) Tidak Ada Ranking dikelas

Sekolah tidak lagi menerapkan peringkat raningking di kelas. Setiap anak dianggap sebagai individu yang unik yang berbedabeda, karena itu tidak bisa disamaratakan pencapaian dan cara belajarnya. Penerapan ranking sama saja artinya menerapkan standarisasi yang sama ke semua anak.

2) Melatih Murid Untuk Berpikir

Anak didik untuk mengutarakan pendapat dan berpikir, bukan sekedar didikte untuk menguasai hapalan dan rumus-rumus dari guru. Yang ditanamkan kepada anak adalah kemampuan untuk memahami konsep dan berpikir secara kritis. Anak dididik untuk menjadi pembelajar (life long learner), bukan hanya sekedar menghapal dan menguasai materi yang diberikan.

3) Tidak Ada Ulangan, Ujian Tengah Semester dan Ujian Akhir Semester

Penilaian murid bukan didasarkan pada tes-tes atau ujian akademik tertulis. Tidak ada yang namanya ulangan harian, masa ujian tengah semester atau ujian akhir semester. Jika tidak ada ulangan dan ujian, lalu bagaimana guru menilai murid? Dan bagaimana anak jadi termotivasi untuk mengadapi ujian?, Justru di sinilah kelebihannya. Ulangan dan ujian hanya akan membuat anak berusaha belajar untuk mencapai tujuan jangka pendek yaitu mendapat nilai, lupakan saja. Ujian ujian seperti itu juga kerap memicu tingkat stres anak ( dan kadang juga orang tua)

Dalam sistem tanpa ulangan dan ujian, justru guru dituntut untuk selalu memper hatikan dan menguji kemampuan murid dalam setiap aktifitas di kelas, termasuk ketika murid mengerjakan tugas-tugas dan projek yang diberikan. Di kelas, murid juga tidak melulu diberikan tugas tertulis, banyak sekali yang sifatnya verbal, diskusi, dan tanya jawab 
dua arah. Di situlah guru harus mengamati dan menilai perkembangan anak setiap saat, yang pada akhirnya guru bisa memberikan nilai. Anak juga jadi didorong untuk selalu bejalar bukan hanya pada saat ujian saja.

4) Tes Diadakan Untuk Assessment Bukan Sekedar Untuk Mendapat Nilai

Memang bukan berarti tidak ada tes tertulis sama sekali, namun tes tertulis dilakukan lebih untuk melakukan assessment dan konfirmasi ulang sudah sampai mana progres kemampuan si anak, apa saja yang sudah dia kuasai, dan apa yang masih harus di-improve lagi ke depannya oleh si anak. Jadi bukan untuk menghakimi atau sekedar mengisi nilai akademik di rapor.

5) Penyampaian Materi Bukan Hanya Satu Arah

Penyampaian materi bukan hanya bersifat satu arah dari guru ke murid, tapi banyak melibatkan tanya jawab, diskusi, bahkan presentasi dari si murid sendiri. Materi-materi tidak hanya disampaikan dalam bentuk teori, tapi murid diajak untuk langsung bereksperimen dengan melakukannya secara nyata. Contohnya, pembelajaran matematika dilakukan dengan metode constructivism di mana anak akan bereksplorasi dengan bendabenda yang konkret terlebih dulu agar memahami konsep, tidak langsung belajar menulis angka-angka di atas kertas. Dalam belajar IPS dan IPA, biasanya ada projekprojek dan misi yang harus dilakukan si anak.

\section{B. 21st Century Skills With 8 Learner Outcomes}

Tujuan belajar bukan sekedar agar si anak menguasai ilmu yang dikotak-kotakkan ke dalam mata pelajaran seperti Matematika, Bahasa, IPA, IPS, kesenian, dan seterusnya, tapi tujuannya adalah untuk membangun manusia yang seutuhnya (the whole child) baik dalam kemampuan akademik maupun kemampuan interpersonal dan intrapersonalnya, tujuannya adalah agar anak pada akhirnya dapat menguasai skill yang diperlukan di abad 21 (21st century skills) meliputi kepercayaan diri (confidence), kemampuan berkolaborasi (collaboration), berpikir kritis (critical thinking), menyelesaikan masalah (problem solving), dan berkomunikasi (communication).

Untuk mencapai tujuan itu, sekolah memiliki framework berupa learner outcomes yang terdiri atas: Audience-centered communication, Creativity and innovation, Expert thinking, Meta-level reflection, Agility and adaptability, Synergistic collaboration, Ethical leadership, Social problem solving, Pelajaranpelajaran yang diberikan saling terkait satu sama lain, dan biasanya dalam satu term (triwulan) ada tema besar yang diusung yang kemudian dielaborasi ke dalam mata-mata pelajaran. Dan semua itu akan mengarah pada penguasaan 8 learner outcomes yang telah dirumuskan di atas.

\section{Sistem multi-age class}

Sekolah ini menerapkan sistem multi-age class, yang artinya dalam 1 kelas terdapat murid-murid dari dua tingkatan kelas sekaligus yang belajar bersama-sama. Misalnya kelas 2 tergabung dengan kelas 3, kelas 4 \& 5, kelas 6 \& 7, dst. Metode ini memiliki banyak keuntungan, antara lain murid jadi dapat saling belajar dari satu sama lain. Anak-anak yang menjadi kakak kelas dapat membimbing anak-anak yang menjadi adik kelas dalam belajar bersama. Filosofinya, ketika kita mengajarkan sesuatu ke orang lain, maka kita sendiri justru akan menjadi lebih paham, dan pemahaman ilmu yang sesungguhnya adalah ketika kita sudah bisa mengajarkan ilmu itu kepada orang lain. Anak juga biasanya akan lebih mudah belajar dari sesama anak seumurnya karena mempunyai "bahasa" yang sama. Selain itu, sistem multiage juga sangat membantu menekan potensi terjadinya bullying atau perundungan. Menurut penelitian, kelas yang hanya berisi anak-anak yang satu umur cenderung membuat anak menjadi bersaing satu sama lain, yang pada akhirnya dapat memicu terjadinya bullying. Sementara kelas yang berisi anak-anak yang berbeda umur justru cenderung akan membantu satu sama lain.

\section{Kolaborasi, bukan kompetisi}

Sekolah ini memang sangat menanamkan nilai kerjasama atau kolaborasi. Berkebalikan dengan pemahaman yang selama ini ada bahwa seorang anak di sekolah harus punya jiwa yang kompetitif, di sekolah ini justru anak diajarkan untuk berkolaborasi dalam banyak hal. Kompetisi hanya akan memberikan persepsi yang salah bahwa kita berprestasi dengan cara mengalahkan orang lain. Padahal kompetisi yang sesungguhnya seharusnya adalah dengan diri kita sendiri, bagaimana kita bisa menjadi diri kita yang lebih baik dibanding diri kita yang sebelumnya, dari hari 
ke hari, dalam segala hal. Dengan bekerjasama, saling membantu, kita akan mencapai hasil yang lebih baik. Karena itulah, sistem ranking sangat tidak relevan.

\section{E. Menguasai calistung bukan syarat masuk Sekolah Dasar}

Sekolah ini termasuk sekolah yang tidak mensyaratkan anak harus bisa membaca, menulis, dan berhitung untuk masuk kelas 1 SD. Logikanya memang kita memasukkan anak ke sekolah agar menjadi pintar, bukan harus pintar dulu agar bisa diterima sekolah. Tes masuk ada, namun lebih untuk melihat kesiapan anak secara sosial emosional dan kesiapan untuk belajar, bukan akademiknya.

\section{F. Sistem bilingual}

Dalam hal bahasa, tentu tidak lupa bahwa kita adalah bagian dari komunitas dunia, dan karena itu sekolah ini menerapkan penggunaan dwi bahasa (bilingual) dengan English sebagai salah satu bahasa wajib sejak dari tingkat usia dini, di samping bahasa ibu, baik untuk komunikasi sehari-hari maupun dalam pelajaran. Anak-anak setingkat SD di sekolah ini rata-rata sudah lancar berbahasa Inggris, namun tidak juga melupakan bahasa ibunya.

\section{G. Nilai-nilai luhur}

Di samping hal-hal yang bersifat akademik, sekolah ini juga berusaha menanamkan nilainilai (values) yang positif kepada anak didik. Salah satu yang sangat menonjol adalah masalah respect atau saling menghargai. Di sekolah ini, perbedaan sangat dihargai, baik itu perbedaan suku, bangsa, sosial ekonomi, maupun agama. Nilai ini begitu terasa sekali dijalankan di sekolah. Semua berbaur dan bekerja sama tanpa memandang adanya perbedaan-perbedaan.

\section{H. Sekolah inklusi}

Sekolah ini dapat menerima anak-anak berkebutuhan khusus yang bersekolah bersama anak yang lain dalam satu kelas. Biasanya anak berkebutuhan khusus didampingi guru khusus, tapi untuk rutinitas dan pembelajaran sehari-hari akan sama dengan anak lainnya. Ini salah satu pembelajaran yang sangat baik juga bagi anakanak mengenai menerima perbedaan dan bagaimana mereka bisa respek terhadap orang berbeda dengan mereka.

\section{Home-school collaboration}

Tentu keberhasilan anak dalam pendidikan tidak hanya bergantung pada pihak sekolah saja. Butuh kerjasama antara orang tua, guru, dan sekolah dalam menunjang keberhasilan anak. Ini bukan sekedar orang tua membantu anak mengerjakan PR di rumah lho ya, tapi orang tua terlibat dalam banyak kegiatan, dan selalu berdiskusi dengan guru. Karena itulah, ketika penerimaan rapot, guru tidak hanya memberikan buku rapot yang berisi nilai-nilai saja, tapi selalu ada diskusi panjang lebar antara guru, orang tua, dan murid itu sendiri. Apa saja pencapaian si anak, apa saja yang masih harus di-improve, rencana pembelajaran ke depan, perilaku anak, dsb. Pada term-term tertentu bahkan si anak sendiri yang mempresentasikan hasil pencapaiannya di depan orang tua dan guru.

\section{SIMPULAN DAN SARAN}

\section{A. Simpulan}

Berdasarkan hasil penelitian dan pembahasan yang telah diuraikan dapat disimpulkan bahwa:

1. Secara umum tujuan dari pembelajaran daring adalah memberikan layanan pembelajaran yang bermutu dalam jaringan (daring) yang bersifat masif dan terbuka untuk menjangkau audiens yang lebih banyak dan luas.

2. Pendidikan ramah anak (PRA) dapat dimaknai sebagai suatu satuan lembaga pendidikan yang dapat memfasilitasi dan memberdayakan potensi anak. Untuk memberdayakan potensi anak di satuan lembaga pendidikan tentunya harus memprogramkan segala sesuatunya yang menyebabkan potensi anak bisa tumbuh dan berkembang, berpartisipasi dan terlindungi dari tindakan kekerasan dan diskriminasi.

3. Pendidikan yang membangun kompetensi "partnership 21st Century Learning" yaitu framework pembelajaran abad 21 yang menuntut peserta didik memiliki keterampilan, pengetahuan, dan kemampuan dibidang teknologi, media dan informasi, keterampilan pembelajaran, inovasi, keterampilan hidup dan Kompetensi "partnership 21st Century Learning" mengacu pada format pendidikan abad 21.

\section{B. Saran}

Berdasarkan kesimpulan maka disam-paikan beberapa saran berikut:

1. Pendidikan yang ramah anak merupakan institusi yang mengenal dan menghargai hak 
anak (untuk memperoleh pendidikan, kesehatan, kesempatan bermain dan bersenang-senang), melindungi dari kekerasan dan pelecehan, dapat mengungkapkan pandangan secara bebas dan berperan serta dalam mengambil keputusan sesuai dengan kapasitas mereka.

2. Dalam rangka menghadapi transformasi Pendidikan abad 21 maka perlu dilakukan penyiapan bagi guru dan siswa dalam melaksanakan kegiatan pembelajar. Transformasi Pendidikan adalah perubahan wajah dan watak yang terjadi pada sistem pendidikan. Dalam rangka meningkatkan compete-nsi dan pengetahuan bagi guru dan siswa dalam mengimplemetasikan pembelajaran maka perlu dilakukan kegiatan sosialisasi, pelatihan atau kegiatan sejenis lainnya secara intensif dan berkelanjutan dalam rangka menyampaikan informasi tentang pembelajaran abad 21 .

3. Rekomendasi untuk peneliti yang lain yaitu penelitian yang dilakukan dalam penelitian ini hanya mengungkap sebagian kecil permasalahan, dalam hal ini masih banyak faktor implementasi pembelajaran ramah anak abad 21, yang dapat ditingkatkan kembali. Untuk itu disarankan kepada peneliti berikutnya yang berminat melakukan penelitian ini lebih lanjut agar dilaksanakan dengan lebih baik.

\section{DAFTAR RUJUKAN}

Agus Suprijono,2009. Cooperative Learning Teori \& Aplikasi PAIKEM. Surabaya: Pustaka Pelajar

Ananda Hadi Elyas, "Penggunaan Model Pembelajaran E-learning dalam Meningkatkan Kualitas Pembelajaran", Jurnal Pendidikan, Edisi 56 April, (Medan : Universitas Darmawangsa 2018), hal. 8-9

Anderson, Ronald H, "Selecting and Developing Media for Instruktion Van Nastrand Reinhold Compay, New York, 1983

Aunurrahman, 2010, Belajar dan pembelajaran. Bandung : Alfabeta.

Bambang Warsita, 2008. Teknologi Pembelajaran Landasan dan Aplikasinya, Jakarta: Rineka Cipta.

Bambang Warsita, Teknologi Pembelajaran,.
E. Mulyasa, 2011, Menjadi Guru profesional, Bandung: PT Remaja Rosdakarya.

Haryanto Al-Fandi, 2011, Desain Pembelajaran yang Demokratis dan Humanis, Yogyakarta : Ar Ruzz Media.

Kokom komalasari, 2010, Pembelajaran Kontekstual Konsep dan Aplikasi. Bandung : PT Refika Aditama.

Latjuba Sofyana, "Pembelajaran Daring Kombinasi Berbasis Whatshap pada Kelas Karyawan Prodi Teknik Informatika universitas PGRI Madiun", Jurnal Nasional Pendidikan Teknik Informatika, Volume 08 Nomor 1 Maret, (Madiun : Teknik informatiak Universitas PGRI 2019), hal. 82

M. Asrorun Ni'am Sholeh, 2016, Panduan Sekolah \& Madrasah Ramah Anak, (Jakarta: Erlangga.

M. Asrorun Ni'am Sholeh,2016. Panduan Sekolah \& Madrasah Ramah Anak, (Jakarta: Erlangga

Muhammad Chodzirin, "Formulasi Model Perkuliahan Daring Sebagai Upaya Menekan Disparitas Kualitas Perguruan Tinggi", Jurnal of Information Technology, Volume 1 Nomor 2, (Semarang : Universitas Islam Negri Walisongo), hal. 153

Muhammad Thobroni dan Arif Mustofa, 2013, Belajar dan Pembelajaran Mengembangkan Wacana Dan Praktik Pembelajaran dalam Pembangunan Nasional, Jogjakarta: ArRuzz Media.

Sitiatafa Rizema Putra, 2013. Desain Belajar Mengajar Kreatif Berbasis Sains. Jogjakarta : Diva Press.

Subagyo, 2014, Aplikasi Pembelajaran Ramah Anak,

Suyono dan Hariyanto, 2011, Belajar dan Pembelajaran, Bandung: PT Remaja Rosdakarya.

Syaiful Sagala, 2011. Konsep dan Makna Pembelajaran untuk Membantu Memecahkan Problematika Belajar dan Mengajar, Bandung: Alfabeta. 
Trianto. 2010, Mendesain model pembelajaran inovatif progresif. Jakarta: Kencana. 2010.

Undang-Undang RI No. 20 tahun 2003 Tentang Sistem Pendidikan Nasional (SISDIKNAS), (Bandung : Citra Umbara, 2008)
UU Nomor 8 Tahun 2014 Tentang Kebijakan Sekolah Ramah Anak

Yusuf Bilfaqih, 2015. "Esensi Pengembangan Pembelajaran Daring", Yogyakarta: CV Budi Utama. 